\title{
Application of the Extended Theory of Reasoned Action to Life Insurance Purchase Decision
}

\author{
Thitapa Na Ranong, Piyamas Suesawadwanit and Apicha Boonpattarakan
}

\begin{abstract}
The purpose of this research was to study the application of the extended theory of reasoned action to life insurance purchase decision. The researchers extended the theory of reasoned action by adding four other essential constructs into the conceptual framework. They were attitude toward saving and attitude toward the brand as well as perceived quality and trustworthiness of salespeople. We collected data from four comparable life insurance companies by asking them to assist in collecting data through their salespeople. We distributed 100 questionnaires to each company. The total was 400 . The usable questionnaires received were 296. When finishing collecting data, we computed Cronbach's alphas to examine the reliability of those constructs with multiple items. The results were satisfactory. Then, we used logistic regression to test our hypotheses because our dependent variable was a binary scale, i.e., purchase or not purchase. The findings showed that attitude toward saving, trustworthiness, attitude toward buying, and perceived quality had significant and positive effects on purchase decision. On the other hand, attitude toward the brand and subjective norm were found to have no effects.
\end{abstract}

Keywords - Attitude, Perceived Quality, Trustworthiness, and Theory of Reasoned Action

\section{INTRODUCTION}

Life insurance can be considered to be a form of financial investment. Although a number of studies about life insurance demand and its value have occurred in most developed countries. The study of such issue has been limited in those emerging markets [1]. Studies about life insurance in developing countries or emerging markets have been limited in the past but they have been an increasing number of studies about life insurance and consumers' decision making in the past few years. Some research found that consumers' personality had an influence on their perceptions and decisions to buy a life insurance policy [2]. The life insurance market can promote economic growth by mobilizing long term funds of the financial markets [3]. The life insurance market is a major component of the financial system of any country. In this perspective, life insurance can be considered an important aspect of financial saving and investment.

Life insurance in Thailand has been gradually increasing in the past few years. Consumers have realized the importance of

Thitapa Na Ranong is with Alliance Pharma Company Limited, Thailand Piyamas Suesawadwanit is with the Faculty of Business Administration, Ramkhamhaeng University, Thailand

Apicha Boonpattarakan is with the Faculty of Business Administration, Ramkhamhaeng University, Thailand having a life insurance policy. In the past, consumers often thought of the association of life insurance with death, not saving. Currently, they slowly understand that life insurance is a form of saving for the future for their immediate family and also when the life insurance holder passes away, his or her immediate family will be taken care of by life insurance coverage.

This research was aimed at investigating the effects of various factors affecting life insurance purchase decision. In this case, the theory of reasoned action was extended to study life insurance purchase decision.

\section{LITERATURE REVIEW}

\section{A. Theory of Reasoned Action (TRA)}

Theory of reasoned action is to try to understand human intention to do something. In the past, theory of reasoned action (TRA) was introduced to predict behaviors [4], [5]. In this theory, two components are proposed to influence behavioral intention, which in turn will influence actual behavior. These two components consist of attitude toward the behavior or attitude toward the act and subjective norm. Attitude toward the act refers to the degree of one's feeling toward a particular behavior. On the other hand, subjective norm refers to the influence of significant others, such as family members, friends, and colleagues; it is the pressure on consumers to conform to the expectations of those significant others. Two elements are expected to influence attitude toward the act. They are behavioral beliefs and outcomes evaluation. Similarly, two elements are proposed to influence subjective norm. These are normative beliefs and motivation to comply. TRA is deemed to be an intuitive and insightful model having the ability to explain behavior [6]. TRA, in addition, has been used to predict different behaviors. It was applied to several types of behaviors, such as intention to conserve water in a lodging context [7], online shopping [8], consumption mode of green electricity [9], food tourist's behavior [10], etc. In this research, attitude toward buying represented attitude toward the behavior, i.e., the purchase of life insurance. We also added two other attitudinal components into the model. These two attitudinal components were attitude toward saving and attitude toward the brand. Subjective norm was also expected to have an influence on life insurance purchase decision. In addition, in life insurance industry, salespersons are essential to the sale of life insurance policies. Hence, perceived quality and trustworthiness of salespersons are important to influence purchase decision.

\section{B. Attitude toward Buying}

According to the TRA, attitude toward the act is an influential 
factor driving people's behavioral intention to do something. Attitude is basically defined as a way people believe or feel about something. It is a psychological construct involving an emotional entity of human beings [11]. Attitude toward the act is basically referred to as people's feeling toward that particular behavior [4]. In this study, attitude toward buying can be defined as a prospective person's feeling toward buying a life insurance policy. If a person feels positive about it, his/her intention to buy a life insurance policy is likely to occur but if a person feels negative about it, his/her intention to buy a life insurance policy is unlikely to occur. This leads to the following hypothesis.

H1: Attitude toward buying will have a positive effect on purchase decision.

\section{Attitude toward Saving}

Economic theories view saving as a surplus of resources after expenditure [12]. On the other hand, behavioral and psychological theory of saving says that saving is dependent on discretionary saving, where one intentionally saves by putting some money aside and may invest for the benefits of having more money in the future [13]. The general thinking of investment is putting some money aside now in order to make gains in the future. Life insurance is comparable to an investment. In the world of digital economy, sellers of life insurance try to point out the saving benefit of life insurance. It means that people can save money by investing in life insurance. They are two major benefits of buying life insurance. One is to cover the life of the life insurance holder if something happens to the life insurance holder. The other one is if the life insurance holder can hold the policy till the end of the period specified in the life insurance policy, which could be 20 or 25 years depending on the terms of the agreement, they will receive a full amount of money plus an attractive incentive. Life insurance holders may also receive some cash back every year or not every year depending on the terms of the agreement. If prospective customers fully understand this, they are more likely to buy a life insurance policy. This leads to the following hypothesis.

H2: Attitude toward saving will have a positive effect on purchase decision.

\section{Attitude toward the Brand}

Attitude toward the brand can be defined as an "individual's internal evaluation of the brand" [14]. This definition involves two key characteristics of attitude. One is that attitude is directed at an object, which is the brand and the other is the internal evaluation of the brand. Consumers may rely on their attitudes toward the brand when forming attitudes toward a company. A brand may also refer to the company itself. Attitude toward the brand can be thought of as consumers' general liking of the brand. Marketing communication can help companies develop a position that can differentiate themselves and attract positive attention from consumers. Brand is an opportunity for a life insurance company to present its brand reputation [15]. Potential customers choose the brand with the image that best fits with their self-image. Companies deliver a promise to customers through the brand, from which expectations are formed. This suggests that attitude toward the brand is an internal part of consumers that may direct behavior. The brand in this case is the life insurance company. If the company is well established and has good reputation. Prospective buyers will feel confident about the brand. Their evaluation of the brand will be positive. It was found that attitude toward the brand had an effect on purchase intention [16]. Hence, the following hypothesis is developed.

H3: Attitude toward the brand will have a positive effect on purchase decision.

\section{E. Subjective Norm}

Subjective norm refers to the perceived social influences that will have an impact on consumers' decision to do or not to do something [17]. Subjective norm is based on the normative beliefs and motivation to comply with those beliefs [17]. In simple words, subjective norm represents the social pressure to engage in a certain behavior [18]. Subjective norm is considered to be the beliefs of consumers on how they should follow the opinion of their reference group if they perform a certain behavior. According to the TRA, subjective norm is a sense of belief about those individuals or/and groups who will approve or disapprove of a particular behavior we are about to engage in [4]. Family members, friends, and colleagues at work may be deemed as the reference group that will have an influence on consumers' purchase decision. As a member of the group, a consumer will try to fit in with the norm of the group. If the reference group feels or thinks positively about buying life insurance, consumers will feel motivated to follow and are more likely to have an intention to do so. Hence, the following hypothesis is derived.

H4. Subjective norm will have a positive effect on purchase decision.

\section{F. Perceived Quality}

Perceived quality can be conceptualized as consumers' judgment about a product's overall excellence. Perceived quality is different from actual quality. It is a higher level abstraction rather than a specific attribute of a product. It is also a global evaluation that in some cases is similar to attitude and a judgment is usually made within a consumer's evoked set [19]. Perceived quality results from the comparison of consumer expectations with the actual performance of a brand. The role of perceived quality in influencing consumer purchase decision in store brands is well supported. It is deemed to be one of the most significant factors in associating the store brand with purchase intention [20]. It is analogous to the perceived quality of a salesperson. Since selling life insurance mostly depends on salespeople, we will apply the concept of perceived quality of a brand to perceived quality of a person. This means that if the salesperson is reliable, knowledgeable, humble, and polite, he/she will create a good self image. This will lead to the likelihood that consumers will make up their minds in a positive way. The following hypothesis is derived. 
H5: Perceived quality will have a positive effect on purchase decision.

\section{G. Trustworthiness}

Trustworthiness has widely been perceived as consisting of ability, benevolence, and integrity [21], [22]. These are three important dimensions that drive people to trust. Trustworthiness is basically based upon the ability, benevolence, and integrity of a person. If the person has these quality aspects, he/she will be trusted [23]. In the past, the concept of trustworthiness was conceptualized as a unidimensional construct or a multi-dimensional construct. As a unidimensional construct, the concept would involve the idea of promise keeping and reliability [24]. As a multi-dimensional construct, the concept would involve the ideas of promise-keeping, honesty, credibility, sincerity, competence, reliability, etc. [25], [26].

In this research, the concept of trustworthiness is based on a unidimensional construct. It can be defined as the ability, benevolence, honesty, and integrity of the salespersons who will perform their tasks faithfully. This is important in the life insurance industry. Creating trustworthiness will help make prospective customers feel confident to buy a life insurance policy. The following hypothesis is suggested.

H6: Trustworthiness will have a positive effect on purchase decision.

\section{RESEARCH CONCEPTUAL FRAMEWORK}

From the literature review, the research conceptual framework is developed and illustrated in Figure 1.

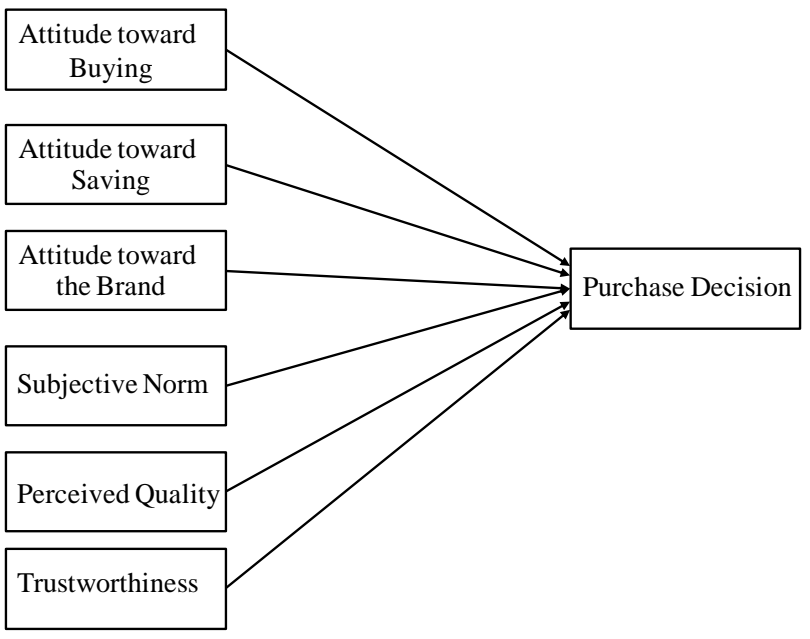

Fig. 1. Research conceptual framework

\section{Methodology}

The population of interest was full-time employees who worked in the Bangkok Metropolitan area in Thailand and had never purchased life insurance policies before. We contacted the marketing directors of the four comparable life insurance companies and asked for their assistance in collecting data. We asked them to give our questionnaires to their salespeople so that they could help collect data when they visited or met with their potential customers. Our sample size would be 384 [27].
We rounded the number up to 400 and requested each life insurance company to help distribute 100 questionnaires through their salespeople.

We then performed in-depth interviews with five marketing directors of the life insurance companies. The purpose was to confirm our conceptual framework and definitions of the constructs. All interviewees agreed with our conceptual framework and definitions. Scales used to measure key constructs were adapted from existing scales [28] and the literature review. We used five point Likert scales to measure our constructs except purchase decision. We used four questions/items for attitude toward the brand and trustworthiness. Three items were used for all other constructs. Purchase decision was based on a binary scale. We used 1 to represent purchase and 0 to represent not purchase. A pretest was then carried out with 50 respondents with the same criterion, i.e., having not purchased a life insurance policy before. The purpose was to check the reliability of the measures. We performed a reliability analysis by examining the Cronbach's alphas. It appeared that the fourth item of trustworthiness was unreliable since its item-total correlation was well below 0.3 [29]. This item was dropped from further analysis. We then recomputed Cronbach's alphas and the results were satisfactory. The Cronbach's alphas for constructs with multiple item scales were above 0.7 [30], the lowest was 0.701 and the highest was 0.882 . This suggested that our measures with multiple items were reliable. A final questionnaire was then developed for data collection.

\section{ANALYSIS AND RESULTS}

We received 302 completed questionnaires back but six of them were unusable. The usable questionnaires were 296 representing a response rate of $74 \%$. We then handled the missing values by replacing them with the mean of their questions/items.

The sample consisted of $35.5 \%$ male and $64.5 \%$ female. The average age of our respondents was 30.86 with standard deviation of 5.68. The majority of respondents had income in the range of Baht 20,000 - 40,000 (76.1\%). In terms of education and marital status, the majority of respondents held a bachelor's degree and a master's degree (95\%) and was single $(66.9 \%)$.

We again performed reliability analysis on those constructs with multiple measures. The results showed that all Cronbach's alphas were above 0.70 [30] indicating good reliability of our measures. The results were presented in Table I.

TABLE I: RESULTS OF RELIABILITY ANALYSIS

\begin{tabular}{|l|c|}
\hline \multicolumn{1}{|c|}{ Constructs } & Cronbach's Alphas \\
\hline Attitude toward Buying & 0.785 \\
\hline Attitude toward Saving & 0.834 \\
\hline Attitude toward the Brand & 0.713 \\
\hline Subjective Norm & 0.705 \\
\hline Perceived Quality & 0.735 \\
\hline Trustworthiness & 0.872 \\
\hline
\end{tabular}


Since our dependent variable/endogenous construct was a binary scale, a logistic regression would be used. Logistic regression is a statistical model used to model a binary dependent variable (nominal scale). The independent variables/exogenous variables can each be a binary variable or a continuous variable (interval scale or ratio scale).

We used logistic regression to analyze the data. Since our exogenous variables were based on multiple questions/items, the composite scores were used for all the exogenous variables. The results were presented in Table II.

TABLE II: RESULTS OF HYPOTHESIS TESTING

\begin{tabular}{|l|c|c|c|}
\hline \multicolumn{1}{|c|}{ Constructs } & Coefficients & $\begin{array}{c}\text { Wald } \\
\text { Chi-square }\end{array}$ & p-value \\
\hline $\begin{array}{l}\text { Attitude toward } \\
\text { Buying }\end{array}$ & 0.452 & 16.354 & $0.000^{* * *}$ \\
\hline $\begin{array}{l}\text { Attitude toward } \\
\text { Saving }\end{array}$ & 0.593 & 16.999 & $0.000^{* * *}$ \\
\hline $\begin{array}{l}\text { Attitude toward } \\
\text { the Brand }\end{array}$ & -0.019 & 0.021 & 0.885 \\
\hline $\begin{array}{l}\text { Subjective } \\
\text { Norm }\end{array}$ & -0.064 & 0.705 & 0.401 \\
\hline $\begin{array}{l}\text { Perceived } \\
\text { Quality }\end{array}$ & 0.248 & 4.157 & $0.041^{*}$ \\
\hline Trustworthiness & 0.473 & 16.831 & $0.000^{* * *}$ \\
\hline
\end{tabular}

*** Significant at 0.001

** Significant at 0.01

* Significant at 0.05

The results indicated that attitude toward buying, attitude toward saving, and trustworthiness were all significant and had positive effects on purchase decision ( $p<0.001)$. Perceived quality was also significant and had a positive effect on purchase decision $(\mathrm{p}<0.05)$. When examining the coefficients, we found that attitude toward saving had the strongest effect, followed by trustworthiness, attitude toward buying, and perceived quality. Attitude toward the brand and subjective norm were found to have no effects on purchase decision. Hence, H1, H2, H5, and H6 were supported whereas $\mathrm{H} 3$ and $\mathrm{H} 4$ were not supported.

\section{DISCUSSION AND IMPLICATION}

The results showed that attitude toward saving had the strongest effect, followed by trustworthiness, attitude toward buying, and perceived quality. The outcome suggests that saving is important to consumers. Consumers can make a long term investment in a life insurance policy because it is a form of saving and the benefit is twofold. One is the coverage of the insurance holder if something happens to him/her. The other one is when the period of the policy is fulfilled, the life insurance holder can receive a lump sum of money. In addition to this, they may get cash back every year or not every year depending on the terms of the life insurance policy. If a consumer feels good about saving, he/she will be more likely to purchase life insurance. According to the TRA theory, attitude toward the behavior/the act will have an effect on behavioral intention. In this sense, attitude toward buying simply just follows the theory. If consumers feel good about buying life insurance policies, it is very likely that they will purchase them. Trustworthiness and perceived quality of salespersons are considered to be very significant factors influencing consumers' purchase decision. Salespeople play a major role in selling life insurance. However, the results suggest that salespeople must have quality in themselves. They must be reliable, knowledgeable, polite, and humble. Apart from all of these quality aspects, the essential one is trustworthy. Salespeople must look trustworthy. They should behave as representatives that consumers can trust when it comes to buying life insurance. Trustworthiness plays a major role in consumers' purchase decision and it is more important than the perceived quality itself. This is true in the real world when trust plays a key role in every situation. If we trust someone, we will listen to that person and do what that person suggests us to do.

Attitude toward the brand was found to have no effect on purchase decision. This may be due to the fact that most brands are well known and have good reputation. As a result, brands are not a factor in consumes' decision making. Subjective norm also had no effect on purchase decision. Buying a life insurance policy is a big step. The person who is deciding must do it by himself/herself. Consumers may listen to others but in the end they will have to decide by themselves.

The implication of the findings is that life insurance companies must focus their communication on saving, not just death coverage or accidental coverage. They must recruit and train their salespeople to be trustworthy, sincere, and willing to help their consumers or clients. In addition to this, salespeople must possess all other quality aspects that will impress consumers or potential customers, such as knowledge about the life insurance, behaving in a courtesy way, and being humble. They also need to look good; appearance can be used as a signal of quality. Life insurance companies may move strategically to focus their resources on marketing communication to create a good and positive feeling toward buying a life insurance policy. They must provide knowledge of life insurance and make consumers aware of it. They also need to make consumers know that life insurance is a form of long term investment that is worth purchasing.

The contribution of this research is the extension of the theory of reasoned action to include other aspects of attitudes. These are attitude toward saving and attitude toward the brand. We also include other key variables associated with the context we are in. These variables/constructs are perceived quality and trustworthiness of salespeople. Future research may want to look beyond the present model to include some other relevant variables/constructs in the model, such as perceived benefits and perceived risks.

\section{CONCLUSION}

The study was aimed at extending the theory of reasoned action to study purchase decision toward buying/purchasing life insurance. Apart from the classic two major components, attitude toward the behavior/the act and subjective norm, that would have a predicted effect on behavioral intention or in this case purchase decision, we also examined the effects of other key constructs involving life insurance. These key constructs were attitude toward saving and attitude toward the brand as 
well as perceived quality and trustworthiness of salespeople. We computed Cronbach's alphas to examine the reliability of all constructs with multiple items. The results were satisfactory. Then, we used logistic regression to test the hypotheses because our dependent variable was based on a binary scale. The findings showed that attitude toward saving, trustworthiness, attitude toward buying, and perceived quality had significant and positive effects on purchase decision but attitude toward the brand and subjective norm were found to have no effects on purchase decision. Future research may want to investigate some other constructs that are considered to have an influential effect on life insurance purchase decision, such as perceived benefits and perceived risks.

\section{REFERENCES}

[1] X. Shi, H. Wang, and C. Xing, "The role of life insurance in an emerging economy: Human capital protection, assets allocation and social interaction," Journal of Banking \& Finance, vol. 50, pp. 19-33, 2015. https://doi.org/10.1016/j.jbankfin.2014.08.028

[2] E. Gambetti, and F. Giusberti, "Personality, decision-making styles and investments," Journal of Behavioral and Experimental Economics, vol. 80, pp. 14-24, 2019. https://doi.org/10.1016/j.socec.2019.03.002

[3] A. L. Alhassan, and N. Biekpe, "Determinants of life insurance consumption in Africa," Research in International Business and Finance, vol. 37, pp. 17-27, 2016. https://doi.org/10.1016/j.ribaf.2015.10.016

[4] I. Ajzen, and M. Fishbein, Understanding Attitudes and Predicting Social Behavior, Englewood Cliffs, NJ: Prentice-Hall Inc, 1980.

[5] M. Fishbein, I. Ajzen, Belief, Attitude, Intention, and Behavior: An Introduction to Theory and Research, Reading, MA: Addison-Wesley, 1975.

[6] R. Bagozzi, "A field investigation of causal relations among cognitions, affect, intentions, and behavior," Journal of Marketing Research, vol. 19, pp. 562-584, 1982. https://doi.org/10.1177/002224378201900415

[7] E. Untaru, A. Ispas, A. N. Candrea, M. Luca, and G. Epuran, "Predictors of individuals' intention to conserve water in a lodging context: The application of an extended theory of reasoned action," International Journal of Hospitality Management, vol. 59, pp. 50-59, 2016 https://doi.org/10.1016/j.ijhm.2016.09.001

[8] A. R. Peslak, and N. Bhatnagar, "A review of internet shopping factors: Do the technology acceptance model or theory of reasoned action model apply?" Issues in Information Systems, vol. 10, no. 2, pp. 495-504, 2009.

[9] Z. Lei, J. Jingxiao, and L. Ruyang, "Research on the consumption mode of green electricity in China-based on theory of reasoned action," Energy Procedia, vol. 5, pp. 938-944, 2011. https://doi.org/10.1016/j.egypro.2011.03.166

[10] Y. H. Kim, M. Kim, and B. K. Goh, "An examination of food tourist's behavior: Using the modified theory of reasoned action," Tourism Management, vol. 32, pp.1159-1165, 2011. https://doi.org/10.1016/j.tourman.2010.10.006

[11] R. M. Perloff, The Dynamics of Persuasion: Communication and Attitudes in the Twenty-First Century, 4th ed., Abingdon, UK: Routledge, 2010.

[12] K. N. Tonsinga, and C. Ghohb, "Savings attitude and behavior in children participating in a matched saving program in Singapore," Children and Youth Services Review, vol. 98, pp. 17-23, 2019. https://doi.org/10.1016/j.childyouth.2018.12.015

[13] G. Katona. Psychological Economics, New York: Elsevier, 1975.

[14] A. A. Mitchell, and J. C. Olson, "Are product attribute beliefs the only mediator of advertising effects on brand attitude?" Journal of Marketing Research, vol. 18, no. 3, pp. 318-332, 1981. https://doi.org/10.1177/002224378101800306

[15] P. Foroudi, "Influence of brand signature, brand awareness, brand attitude, brand reputation on hotel industry's brand performance," International Journal of Hospitality Management, vol. 76, pp. 271-285, 2019.

https://doi.org/10.1016/j.ijhm.2018.05.016
[16] N. Spears, and S. N. Singh, "Measuring attitude toward the brand and purchase intentions," Journal of Current Issues \& Research in Advertising, vol. 26, no. 2, pp. 53-66, 2004. https://doi.org/10.1080/10641734.2004.10505164

[17] I. Ajzen, "The theory of planned behavior," Organizational Behavior and Human Decision Processes, vol. 50, no. 2, pp. 179-211, 1991. https://doi.org/10.1016/0749-5978(91)90020-T

[18] I. Ajzen, and M. Fishbein, "The influence of attitudes on behavior," in D. Albarracín, B. T. Johnson, and M. P. Zanna, (Eds), The Handbook of Attitudes, Lawrence Erlbaum Associates, Mahwah, NJ, pp. 173-221, 2005.

[19] V. A. Zeithaml, "Consumer perceptions of price, quality and value: A means-end model and synthesis of evidence," Journal of Marketing, vol. 52, pp. 2-22, July 1988. https://doi.org/10.1177/002224298805200302

[20] G. Baltas, and P. C. Argouslidis, "Consumer characteristics and demand for store brands," International Journal of Retail \& Distribution Management, vol. 35, no. 5, pp. 328-341, 2007. https://doi.org/10.1108/09590550710743708

[21] R. C. Mayer, J. H. Davis, and F. D. Schoorman, "An integrative model of organizational trust," Academy of Management Review, vol. 20, pp. 709-734, 1995. https://doi.org/10.5465/amr.1995.9508080335

[22] H. Gill, K. Boies, J. Finegan, and J. McNally, "Antecedents of trust: Establishing a boundary condition for the relation to propensity to trust and intention to trust," Journal of Business \& Psychology, vol. 19, no. 3, pp. 287-302, 2005 . https://doi.org/10.1007/s10869-004-2229-8

[23] C. Caldwell, and L. Hayes, "Leadership, trustworthiness, and the mediating lens," Journal of Management Development, vol. 26, no. 3, pp. 261-278, 2007. https://doi.org/10.1108/02621710710732155

[24] C. Moorman, R. Deshpandé, and G. Zaltman, "Factors affecting trust in market research relationships," Journal of Marketing, vol. no. 1, pp. 81-101, 1993. https://doi.org/10.1177/002224299305700106

[25] S. Ganesan, "Determinants of long-term orientation in buyer-seller relationships," Journal of Marketing, vol. 58, no. 2, pp. 1-19, 1993. https://doi.org/10.1177/002224299405800201

[26] L. A. Crosby, K. R. Evans, and D. Cowles, "Relationship quality in services selling: An interpersonal influence perspective," Journal of Marketing, vol. 54, no. 3, pp. 68-81, 1990. https://doi.org/10.1177/002224299005400306

[27] R. V. Krejcie, and D. W. Morgan, "Determining sample size for research activities," Educational and Psychological Measurement, vol. 30, pp. 607-610, 1970 https://doi.org/10.1177/001316447003000308

[28] J. E. Lee, and L. Stoel, "High versus low online price discounts: Effects on customers' perception of risks," Journal of Product \& Brand Management, vol. 23, no. 6, pp. 401-412, 2014. https://doi.org/10.1108/JPBM-06-2014-0633

[29] A. Field, Discovering Statistics Using SPSS, 2nd ed., London: Sage, 2005.

[30] J. C. Nunnally, Psychometric Theory, 2nd ed., New York, NY: McGraw-Hill, 1978. 